STUDIA HISTORYCZNE

R. LX, 2017, z. 4 (240), s. 83-85

\title{
Mariusz Borowiak, „Pancerniki na Morzu Pińskim” 1920-1941, Oświęcim: Wydawnictwo Napoleon V, 2016, ss. 346, ISBN 978-83-65495-97-6
}

Czasy II Rzeczypospolitej pozostają w polskiej historiografii okresem obrosłym licznymi mitami, wciąż budzącym wielkie emocje zarówno wśród historyków, jak i czytelników. O temperaturze tych uczuć może świadczyć chociażby zażarta polemika dotycząca książki Stracone szanse września '39², stoczona na łamach czasopisma „Wojsko i Technika - Historia" przez jej autora z Edwardem Malakiem ${ }^{3}$. Okres międzywojenny pozostaje także pełen wciąż nieznanych lub wymagających ponownego opisania epizodów. Jednego z takich tematów podjął się w swojej najnowszej książce Mariusz Borowiak, skądinąd także autor niepozbawiony kontrowersji ${ }^{4}$.

Książka Mariusza Borowiaka składa się z 12 rozdziałów w układzie chronologiczno-problemowym. Pierwszy, Powstanie Polskiej Marynarki Wojennej oraz idea budowy monitorów rzecznych w latach 20. XX w., przedstawia zarówno genezę polskiej floty po odzyskaniu niepodległości oraz bardzo ważną rolę jej rzecznego komponentu, jak i walki prowadzone przez jednostki bojowe młodego państwa z bolszewikami. Autor pokrótce omawia także w tej części książki stan Flotylli Pińskiej, gdy w roku 1927 komendę nad nią objął komandor Witold Zajączkowski, oraz reformy, które musiał on wprowadzić. Rozdział zamyka krótki rys historii monitorów jako klasy okrętów wojennych.

Rozdziały II-VI poświęcone są planom lub budowie monitorów rzecznych dla PMW. Borowiak przedstawia $\mathrm{w}$ nich koncepcje $\mathrm{z}$ różnych powodów niezrealizowane zarówno w latach 20. XX wieku (plany monitorów typu A, C i Z), jak i w następnej dekadzie (typy LM, CM, MC). Osobne rozdziały poświęcone są zbudowanym w roku 1920 w Gdańsku czterem monitorom typu „Warszawa” (Rozdział III) oraz ich dwóm młodszym „braciom” zbudowanym w Krakowie (Rozdział V). Wspomniany rozdział poświęcony okrętom „Warszawa”, „Toruń”, „Pińsk” i „Horodyszcze” zawiera także opis ich służby na Wiśle w latach 1921-1925.

Rozdział VII przedstawia coroczne kampanie monitorów na tzw. Morzu Pińskim, począwszy od reaktywacji polskiej obecności nawodnej w tamtym rejonie po zakończeniu wojny z bolszewikami, aż do progu II wojny światowej. Okresowi bezpośrednio przed

2 A. Bolest a, Stracone szanse września '39, Warszawa 2015, ss. 320.

3 E. Malak, „Stracone szanse WRZEŚNIA'39”. Stracona szansa na obiektywne spojrzenie, „Wojsko i Technika - Historia” 2016, nr 5; A. Bolesta, Stracone szanse WRZEŚNIA'39. Polemika autorska, „Wojsko i Technika - Historia" 2017, nr 1.

4 Największe kontrowersje wywołała chyba jego książka Plamy na banderze (Warszawa 2007). 
wybuchem tego konfliktu poświęcony jest następny rozdział: $W$ przededniu wojny obronnej 1939 r. Kolejne dwa rozdziały (Wojenne losy monitorów na Polesiu i Agresja sowiecka) przedstawiają tragiczne wojenne losy okrętów i marynarzy Flotylli Pińskiej, m.in. konieczność zatopienia własnych jednostek, walki lądowe spieszonych żeglarzy i zbrodnie najeźdźców, takie jak mord w Mokranach.

Rozdział XI, Polskie monitory w sowieckiej Flotylli Pinskiej 1939-1941, przedstawia służbę byłych polskich monitorów pod czerwonym sztandarem. Z sześciu „rzecznych pancerników” wysadzony w powietrze został tylko okręt „Wilno”. Pozostałe, zatopione w płytkich wodach poleskich rzek, zostały przez Sowietów szybko podniesione i wyremontowane. W efekcie cała piątka brała udział w walkach po agresji niemieckiej na Związek Radziecki, do września 1941 roku wszystkie okręty uległy jednak zniszczeniu. Ostatni, XII rozdział poświęcony jest współczesnym działaniom polsko-ukraińskim związanym ze zlokalizowaniem wraku ORP „Kraków” (późniejszy sowiecki „Smoleńsk”) i pomysłom na zagospodarowanie resztek zatopionej jednostki.

Książka opatrzona jest przypisami, bibliografią i wykazem skrótów. Posiada bogaty materiał ilustracyjny w postaci licznych zdjęć, rysunków technicznych oraz map. Zabrakło niestety indeksu, co przy stosunkowo sporej objętości jest minusem.

Zagadnienie przedstawione w omawianej publikacji nie jest dla M. Borowiaka czymś nowym - o polskiej flotylli rzecznej z Pińska pisze on już regularnie od początku lat 90. XX wieku, zaś Pancerniki... są jego kolejną pozycją szczegółową dotyczącą Flotylli Pińskiej, po wydanych w roku 2014 Statkach uzbrojonych Flotylli Pinskiej5. W efekcie otrzymujemy książkę obszerną i pełną zarówno unikalnych fotografii, jak i pieczołowicie zebranych przez autora relacji ustnych oraz wspomnień. Oprócz tego główny tekst wzbogacony jest o dodatkowe informacje zawarte w ramkach, w których autor umieścił opisy uzbrojenia będącego na wyposażeniu monitorów oraz historię działalności szpiegowskiej prowadzonej na rzecz Niemiec przez jednego z oficerów Floty Pińskiej.

Książka napisana jest sprawnym piórem, choć da się odczuć, że poszczególne rozdziały powstawały osobno lub w pewnych odstępach czasowych. W efekcie pewne wydarzenia, które pojawiły się już w tekście, przedstawiane są czytelnikowi po raz kolejny, np. przejście monitorów rzecznych na Wybrzeże i odbycie tam ćwiczeń w 1924 roku.

Praca M. Borowiaka jest obszerna i zawiera informacje nie tylko o samych monitorach i ich służbie w polskich flotyllach rzecznych, ale także przykładowo ogólny zarys sytuacji polskiej Marynarki Wojennej w okresie międzywojennym (a zwłaszcza w latach 20.) i jej komponentu rzecznego, informacje o rozbudowie Flotylli Pińskiej i związanym z nią rozwojem Pińska itp. Szczegółowo omówiony jest zwłaszcza proces projektowania nowych jednostek, ich parametry techniczne, włącznie z rysunkami technicznymi okrętów, nawet tych, które ostatecznie nie powstały.

5 M. B o rowiak, Statki uzbrojone Flotylli Pińskiej, Warszawa 2014. 
W tym kontekście szkoda, że stosunkowo pobieżnie przedstawiona jest codzienna służba „granatowej braci” na monitorach. O ile w książce rozsiane są tu i ówdzie różne ciekawe informacje - już we wstępie dowiadujemy się, że niezwykle dokuczliwym problemem były komary i roznoszona przez nie malaria ${ }^{6}$ - to autor nie poświęcił kwestii „ludzkiej” zbyt wiele miejsca. Jest to o tyle przykre, że z jednej strony możemy przeczytać o problemach z dyscypliną, począwszy od awanturujących się w Pińsku marynarzy, po oficerów de facto zsyłanych karnie na Polesie z Wybrzeża. Z drugiej, opisane przez autora zachowanie oficerów i marynarzy po otrzymaniu rozkazu zatopienia okrętów we wrześniu 1939 roku pokazuje głębokie przywiązanie do swoich jednostek i patriotyzm marynarzy Flotylli Pińskiej. W tym kontekście brak przedstawienia dnia codziennego na monitorach w trakcie corocznych kampanii oraz szerszego zarysowania relacji pomiędzy kadrą oficerską i marynarzami uznać trzeba za minus. Niestety wydaje się, że „rzeczne pancerniki” odrobinę przesłoniły w książce marynarzy pełniących na nich służbę.

Mimo powyższego zastrzeżenia dzieło M. Borowiaka jest zdecydowanie godne polecenia. Autor pieczołowicie przedstawił historię powstania polskich monitorów i dzieje ich służby. Książka posiada także liczne tabele oraz spisy ułatwiające, przykładowo, ustalenie oficera dowodzącego danym okrętem w konkretnym okresie. Choć zdarzają się w niej niekiedy literówki, stanowi przystępne i sprawnie napisane źródło informacji dla każdego zainteresowanego Flotyllą Pińską, zarówno dla osób dopiero odkrywających tę tematykę, jak i dla badaczy zagadnienia.

Jarema Stowiak

6 Id e m, „Pancerniki na morzu pińskim” 1920-1941, Oświęcim 2016, s. 8. 